\title{
The Impact of COVID-19 on Travelers' Travel Behavior
}

\author{
Ayse Collins ${ }^{1}$, Valentina Della Corte ${ }^{2}$, Giovanna Del Gaudio ${ }^{2}$, Cihan Cobanoglu $\&$ Anna Crisci ${ }^{2}$ \\ ${ }^{1}$ Faculty of Applied Sciences, Bilkent University, Ankara, Turkey \\ ${ }^{2}$ University of Naples Federico II, Naples, Italy \\ ${ }^{3}$ School of Hospitality \& Tourism Management, University of South Florida, USA \\ Correspondence: Ayse Collins, Faculty of Applied Sciences, Bilkent University, Ankara, Turkey. E-mail: \\ collins@bilkent.edu.tr
}

Received: July 13, 2021

Accepted: November 17, 2021

Online Published: December 31, 2021

doi:10.5539/ijbm.v17n2p1

URL: https://doi.org/10.5539/ijbm.v17n2p1

\begin{abstract}
The purpose of this paper is to investigate the impact of a global pandemic, Coronavirus (COVID-19), on travel behavior by integrating crisis management with other behavior variables. Online surveys via the Amazon Mechanical Turk website were used for data collection. A total of 1978 responses were collected from 19 countries (September, 2020); 1607 valid cases were undertaken for the data analysis. The results suggest that crisis management intervention was the most influential factor impacting travel behavior during the COVID-19 pandemic. Non-pharmaceutical interventions followed as the second most influencing predictor. . Personal traits were the only variable that recorded a negative relationship with travel behavior. This study has significant practical and theoretical implications since it adopted the extended model of goal-directed behavior while including crisis management intervention, which is a unique approach. Although attitudes generally strongly influence travel behavior, in a pandemic situation, such relationships weaken. In terms of practical implications, it has become apparent that firms and governments should implement integrated risk management and crisis management strategies. Travelers need to be reassured that these tourist destinations have become safe again. This will likely decrease the risk factor, therefore influencing them to travel to this region. This study contributes to understanding how a global pandemic influences travel behavior It will be invaluable in predicting the early reflections of travelers as the pandemic ends.
\end{abstract}

Keywords: crisis management, COVID-19, Extended Model of Goal Behavior

\section{Introduction}

\subsection{Introduce the Problem}

Following six decades of continued growth, tourism is one of the world's most important and fastest-growing service sector economies - creating jobs, stimulating regional development and supporting local communities ("OECD Tourism Trends and Policies", 2020). Unlike other industries, tourism is not one clear product; it incorporates many industries including Lodging, Transportation, Attractions, Travel Agent's, Tour Groups and local services, i.e., Restaurants, Tour Guides, Dry Cleaning, etc. (Thomala, 2020). After the influenza A (H1N1) virus in 2009-2010 ("Past Pandemics" n.d.), the world, once again, faced the reality of how local outbreaks of an infectious disease become global pandemics. The local outbreak in Wuhan Province, China, opened the route for a global pandemic of Coronavirus (COVID-19) (Normile, 2020). When looking at records of epidemics prior to H1N1 and Coronavirus, the world population experienced epidemic outbreaks of SARS (Severe Acute Respiratory Syndrome) in 2003 and swine flu in 2009. The Coronavirus outbreak was declared a Public Health Emergency of International Concern on 30 January 2020 and recognized as a pandemic on 11 March 2020 (Ghebreyesus, 2020). In the end, "travel and tourism themselves became the victims" (Wilder-Smith, 2006) due to regulatory restrictions and the crisis psychology of the general population.

To limit the spread of the virus, a series of drastic actions was taken globally: canceling both outbound and inbound international and national flights (Schaper, 2020); strictly controlling land and sea borders (Salcedo et al., 2020); restricting citizens' mobility (North, 2020) and 4) announcing public restrictions like wearing masks, social distancing and forbidding gatherings (Sheikh, 2020), 5) closing retail and public recreation spaces (Thomas and Berk, 2020). Moreover, a significant number of cruises, conferences, cultural and sporting events were postponed. 
These measures had a direct negative impact on tourism and associated industries which rely on tourism such as agriculture, laundries, local souvenir markets, and manufacturing. Similarly, indirect impacts have been observed in other sectors, such as the oil industry where prices fell $49.5 \%$ from one year ago (David, 2020).

As the Coronavirus spreads around the globe, it is also taking a toll on global tourism, and economists predict that the impact on economic growth will be great ("Deeper Revenue Hit from COVID-19", 2020). Overall, this uncertain and unexpected situation, coupled with the psychological impacts of Coronavirus, have created a high economic cost due to the loss of confidence (Vinelli et al., 2020). Therefore, this study aims at investigating the impact of a specific global pandemic, COVID-19, on travel behavior by integrating crisis management and looking through the lens of travelers.

\section{Review of the Literature}

\subsection{Decision Making}

The literature on decision making concerning both leisure and business travel after man-made or natural disasters is extensive (Al-Tawfiq et al., 2014; Filimonau and De Coteau, 2020; Sundling et al., 2016), but it deals with different and fragmented perspectives (Biggs et al., 2012; Wen et al., 2005) such as financial and economic instability, political crisis, the increasing price of oil and changes in the global environment. The contributions in the literature have explored the phenomena of disasters and crises (natural disasters, epidemic disasters, political and economic crises, etc.) by studying their impacts in the following years in order to explore the precise motivations of travel behavior (Lee et al., 2012; Wen et al. 2005). These studies concluded that effective communication systems and emergency measures are vital to recovering the damage in the tourist market.

In order to have a clear vision of travelers' behavior, previous studies have used the Theory of Reasoned Action and the Theory of Planned Behavior (Montano and Kasprzyk, 2015; Lee et al., 2012). Usually, the Theory of Planned Behavior is considered an expansion of the Theory of Reasoned Action since it includes the "perceived control over the performance of the behavior" (Montano and Kasprzy, 2015 p. 68). The Theory of Planned Behavior adds the perceived control constituted by perceived power and control beliefs.

The literature is advanced by the model of goal-directed behavior, which includes other important variables such as affective process, motivational process and past behavior (Lee et al., 2012). Indeed, the Theory of Reasoned Action, the Theory of Planned Behavior, and goal-directed behavior models do not consider events, such as a virus or other epidemic crises, that influence travelers' behavior. Therefore, some scholars have recently developed an Extended Model of Goal Behavior (EMGB) with more variables in order to predict the process of how travelers actually decide (Kim et al. 2017; Kim and Preis, 2016; Meng and Choi, 2016). However, those studies have not considered "crisis management" as one of the variables that can affect the decisions of travelers during a pandemic. Therefore, in this study, EMGB is studied by adding "crisis management" to the previous variables: frequency of past behavior, attitude, positive/negative personal traits, perceived behavioral control and non-pharmaceutical interventions.

\subsection{Crisis Management Interventions}

Several authors (Avci et al., 2011; Bundy et al., 2017; Campo et al., 2014; Mansour et al., 2019) have provided definitions of "crisis management" as the process of how organizations react to disruptive and unexpected events harming both the organization and its stakeholders. From the perspective of the tourism/travel industry, a crisis can be defined as an event and/or circumstances that result in damage to the reputation, sales and operations of destinations and organizations within a tourism region (Pasteur, 2016), which creates major concerns for travelers. Zech (2016) developed a crisis typology (Table I), which showed each crisis type and its macro and/or micro impact levels. 
Table 1. Crisis typology and impacts

\begin{tabular}{ll}
\hline Crisis type & Major impact level \\
\hline Economic crisis & Macro \\
Environment crisis & Macro/micro \\
Health crisis & Macro/micro \\
Informational/reputational crisis & Micro \\
Structural crises & Macro/micro \\
Political crises & Macro \\
Sociocultural crisis & Macro/micro \\
Technological crisis & Macro/micro \\
\hline
\end{tabular}

There need to be more studies that focus on topics from multi-dimensional views such as integrating crisis management with the changes in travelers' behavior, which is the main focus of this paper. Therefore, in the light of the above crisis management definition, the rest of this review will present a broader perspective of "travelers' behavior" by taking into account travelers' specific perceptions of the epidemic diseases/virus, their voluntary personal practices while traveling and changes in their behavior. This paper adopts the extended model of goal-directed behavior during the crisis period, in this case COVID 19, by taking into account the holistic process of traveler's travel behavior. In light of the discussed literature, the following hypotheses were developed:

Hp1: Attitude (AT) has a positive influence on travel behavior (TB)

Hp2: Personal traits (PT) have a positive influence on travel behavior

Hp3: Crisis Management Interventions (CM) have a positive influence on travel behavior

Hp4: Perceived Behavioral Control (PBC) has a positive influence on travel behavior

Hp5: Non-Pharmaceutical Interventions (NPI) have a positive influence on travel behavior

The conceptual model of the study is given in Figure 1.

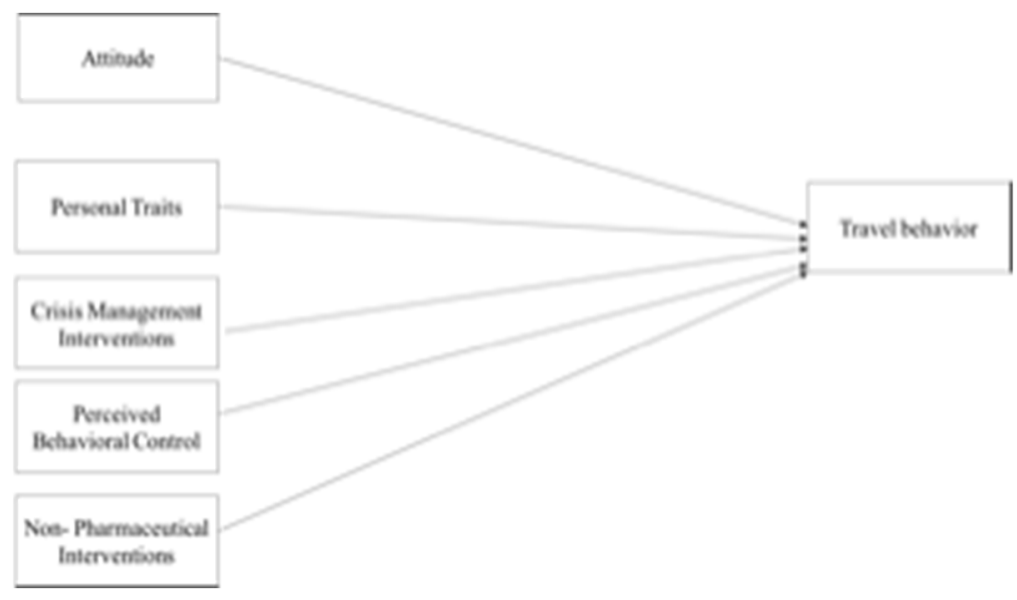

Figure 1. The Conceptual Model of the Study

\section{Results}

This study adopted a quantitative approach in order to reach a broader audience quickly (Enright and Newton, 2004). To test the hypotheses, we adopted the Partial Least Squares-Path Modeling (PLS-PM) algorithm using 
the module R-package. The purpose of PLS-PM is to estimate the relationships among Q blocks of variables.

We consider $\mathrm{K}$ variables manifest on $\mathrm{N}$ subject $(\mathrm{n}=1, \ldots, \mathrm{N})$. The data $\mathrm{x} \_\mathrm{nkq}$ were collected in a partitioned data matrix X:

$$
\mathrm{X}=\left\{\mathrm{X} \_1, \cdots, \mathrm{X} \_(\mathrm{q},) \cdots \dashv \vdash \quad \vdash, \mathrm{X} \boldsymbol{C}_{-} \mathrm{Q}\right\}
$$

A PLS path model involves two parts: the measurement model (or outer model), which defines the relationships between the manifest variables (MVs) and their respective latent variable (LV) $\xi_{-} \mathrm{q}$, and the structural model (or inner model), which defines the relationships between the LVs.

The Inner Model can be written as (Vinzi et al. $2010 \mathrm{a}, \mathrm{b}$ ):

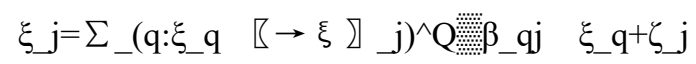

where $\xi_{-} \mathrm{j}(\mathrm{j}=1, \ldots, \mathrm{J})$ is the endogenous latent variable, $\beta_{-} \mathrm{qj}$ is the path coefficient connecting the $\mathrm{q}$-th exogenous latent variable to the $\mathrm{j}$-th endogenous, and $\zeta \mathrm{j}$ is the error in the inner relation.

In the Measurement model, two ways to link each of the manifest variables (MVs) to its latent variable (LVs) can be distinguished:

Reflective way: MVs (X_kq) are considered to be reflections of their latent variables $\zeta\left(\xi \nabla \_q\right)$ :

$$
\mathrm{X}_{-} \mathrm{kq}=\lambda \_\mathrm{kq} \xi \_\mathrm{q}+\varepsilon_{-} \mathrm{kq}
$$

where $\lambda \mathrm{kq}$ is the loading coefficient, and $\varepsilon_{-} \mathrm{kq}$ is a zero mean random term uncorrelated with the latent variable $\xi_{-}$q.

Formative way: MVs $\square\left(\mathrm{X} \rrbracket \_\mathrm{kq}\right)$ are considered as causes of their latent constructs $\square\left(\xi \nabla_{-} \mathrm{q}\right)$ :

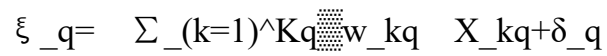

where $w_{-} \mathrm{kq}$ is the coefficient connecting each MV to the corresponding $\mathrm{LV}$, and the error term $\delta_{-} \mathrm{q}$ is a zero mean random term uncorrelated with the manifest variable.

LV estimates $\left(\xi_{-}^{\wedge} q\right)$ by means of the weight relations are defined as follows:

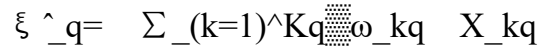

where $\omega_{-} \mathrm{kq}$ are the outer weights used to estimate the LVs as linear combinations of their observed MVs.

The PLS algorithm considers two double approximations for the latent variables: a) external estimation, obtained as the product between the block of manifest variables and the outer weights; $b$ ) internal estimation obtained as the product between the external estimation and the so-called inner weights. Then, the parameter estimation is performed through the alternation of the external and the internal estimations, iterating until convergence. The paths among the LVs are got through the ordinary least squares (OLS).

\subsection{Survey Instrument}

To ensure validity, all the items used were adopted from previous studies. Five items were created by the authors since the measures taken during this pandemic are unique and therefore could not be adapted from an existing study. The questionnaire covered the possible impacts of Coronavirus on respondents in terms of general impact, attitude and preferences, safety, and hygiene. A 5-point Likert scale was used, and participants were asked to rate their level of agreement according to their own judgment. The questionnaire continued with a demographics section and a final question about the likelihood of traveling in the future (George and Swart, 2012). attention check questions were used to ensure validity.

\subsection{Sample}

Through Amazon Mechanical Turk ${ }^{\mathrm{TM}}$ (MTurk), the questionnaire was distributed in the mode of a self-administered online questionnaire, and each participant was paid $\$ 0.15$ cents. To ensure quality data collection, several actions were taken, as Cobanoglu et al. (2016) suggested. These are: 1) sending the survey to only users with an approval rate of $95 \%$ or higher; 2 ) implementing several attention check questions inside the survey (i.e., please select "agree" from the responses below) and removing the ones that do not pass these checks; 3) disabling the possibility of taking the survey more than once from the same internet protocol address.

\section{Results}

\subsection{Demographics}

A total of 1978 responses were collected from 19 countries (September 2020). Incomplete questionnaires and the responses that did not pass the validity questions were removed, and the final number for valid and complete 
surveys was 1607. Among these 1607 respondents, a total of 750 (47\%) are male and 857 (53) are female. In terms of age, the most substantial portion was between 18 and 35 years old (50\%). Thirty-eight percent of the respondents have a master's degree, and nearly $18 \%$ have a college associate degree. A monthly income of $\$ 20,000$ to $\$ 29,999$ comprised the largest group (14\%). People working in management, professional and related sectors accounted for $38 \%$ of all participants. Most of the respondents traveled at least once in six months (32\%).

Table 2. Demographics

\begin{tabular}{|c|c|}
\hline Variable & $(\%)$ \\
\hline \multicolumn{2}{|l|}{ Gender } \\
\hline Female & 53 \\
\hline Male & 47 \\
\hline Level of education & 1 \\
\hline Less than high school degree & 9 \\
\hline High school graduate (high school diploma or equivalent-including GED) & 18 \\
\hline Some college but no degree & 10 \\
\hline Associate degree in college (2-year) & 38 \\
\hline Bachelor's degree in college (4-year) & 17 \\
\hline Master's degree & 4 \\
\hline Doctoral degree & 3 \\
\hline \multicolumn{2}{|l|}{ Professional degree (JD, MD) } \\
\hline \multicolumn{2}{|l|}{ Income } \\
\hline Less than $\$ 10,000$ & 10 \\
\hline$\$ 10,000$ to $\$ 19,999$ & 10 \\
\hline$\$ 20,000$ to $\$ 29,999$ & 14 \\
\hline$\$ 30,000$ to $\$ 39,999$ & 10 \\
\hline$\$ 40,000$ to $\$ 49,999$ & 12 \\
\hline$\$ 50,000$ to $\$ 59,999$ & 10 \\
\hline$\$ 60,000$ to $\$ 69,999$ & 8 \\
\hline$\$ 70,000$ to $\$ 79,999$ & 6 \\
\hline$\$ 80,000$ to $\$ 89,999$ & 5 \\
\hline$\$ 90,000$ to $\$ 99,999$ & 4 \\
\hline$\$ 100,000$ to $\$ 149,999$ & 8 \\
\hline$\$ 150,000$ or more & 3 \\
\hline \multicolumn{2}{|l|}{ Age group, years } \\
\hline $18-35$ & 50 \\
\hline $36-55$ & 33 \\
\hline 55 above & 17 \\
\hline \multicolumn{2}{|l|}{ Occupation } \\
\hline Management, professional, and related & 38 \\
\hline Service & 17 \\
\hline Sales and office & 14 \\
\hline Farming, fishing, and forestry & 1 \\
\hline Construction, Extraction, and maintenance & 3 \\
\hline Production, transportation, and material moving & 4 \\
\hline Government & 7 \\
\hline Retired & 4 \\
\hline Unemployed & 12 \\
\hline \multicolumn{2}{|l|}{ Frequency of travel for leisure or business } \\
\hline Once a week & 2 \\
\hline Once a month & 9 \\
\hline Once every other month & 15 \\
\hline Once every six months & 32 \\
\hline Once a year & 22 \\
\hline Less than once a year & 20 \\
\hline
\end{tabular}




\subsection{Hypothesis Testing}

In order to check the quality of the outer model we verified the unidimensionality of the reflective MVs block. We checked the unidimensionality of the manifest variables blocks through Dillon-Goldstein's rho. A block is unidimensional if the Dillon-Goldstein's rho (DG rho) is greater than 0.7. In our case, the value of the DG rho is $>0.7$ for all the manifest variables blocks.

Afterwards, we assessed the convergent validity using the Average Variance Extracted (AVE $\geqslant 0.50$ ). AVE attempts to measure the amount of variance that a latent variable captures from its indicators in relation to the amount of variance due to measurement error. In our research, AVE is usually equal to or greater than 0.50 .

To validate a PLS-PM globally we consider the Goodness of Fit (GoF), which is a compromise between the quality of the measurement model and the quality of the structural model. An acceptable GoF of 0.5855 was obtained. Moreover, a satisfying coefficient of determination R2 (0.67) for the endogenous latent variable travel behavior was obtained.

Table III shows the bootstrap results for the Outer Model (loading coefficients). The confidence intervals indicate that the regression coefficients are significant. If a confidence interval does not include zero, the hypothesis that the parameter is equal zero is rejected. The loading coefficients (Table III) are positive (except the loading for PT2) and significant (the confidence intervals never include zero).

Table 3. Bootstrap results for loading coefficients

\begin{tabular}{llllll}
\hline & Original & Mean.Boot & Std.Error & perc.025 & perc. 975 \\
\hline AT-AT1 & 0.646 & 0.646 & 0.02153 & 0.607 & 0.684 \\
AT-AT2 & 0.755 & 0.754 & 0.01298 & 0.726 & 0.775 \\
AT-AT3 & 0.694 & 0.695 & 0.01746 & 0.670 & 0.731 \\
AT-AT4 & 0.544 & 0.548 & 0.02074 & 0.532 & 0.605 \\
AT-AT5 & 0.704 & 0.706 & 0.01457 & 0.674 & 0.728 \\
PT-PT1 & 0.477 & 0.483 & 0.05908 & 0.365 & 0.597 \\
PT-PT2 & -0.840 & -0.836 & 0.03447 & -0.893 & -0.757 \\
CM-CM1 & 0.570 & 0.573 & 0.02169 & 0.536 & 0.616 \\
CM-CM2 & 0.672 & 0.674 & 0.01750 & 0.646 & 0.705 \\
CM-CM3 & 0.754 & 0.755 & 0.01165 & 0.732 & 0.776 \\
CM-CM4 & 0.799 & 0.801 & 0.00986 & 0.782 & 0.819 \\
CM-CM5 & 0.714 & 0.716 & 0.01419 & 0.681 & 0.745 \\
CM-CM6 & 0.790 & 0.791 & 0.00954 & 0.775 & 0.808 \\
CM-CM7 & 0.682 & 0.680 & 0.01464 & 0.653 & 0.707 \\
CM-CM8 & 0.628 & 0.628 & 0.01848 & 0.594 & 0.663 \\
CM-CM9 & 0.715 & 0.715 & 0.01499 & 0.680 & 0.746 \\
PBC-PB1 & 0.637 & 0.637 & 0.01852 & 0.601 & 0.669 \\
PBC-PB2 & 0.849 & 0.850 & 0.00808 & 0.832 & 0.864 \\
PBC-PB3 & 0.863 & 0.863 & 0.00740 & 0.850 & 0.876 \\
PBC-PB4 & 0.871 & 0.872 & 0.00667 & 0.859 & 0.884 \\
NPI-NPI1 & 0.871 & 0.870 & 0.00888 & 0.851 & 0.886 \\
NPI-NPI2 & 0.862 & 0.861 & 0.00926 & 0.843 & 0.880 \\
NPI-NPI3 & 0.843 & 0.845 & 0.01087 & 0.825 & 0.865 \\
NPI-NPI4 & 0.752 & 0.754 & 0.01375 & 0.728 & 0.777 \\
NPI-NPI5 & 0.849 & 0.850 & 0.01049 & 0.830 & 0.869 \\
TB-TB1 & 0.560 & 0.555 & 0.02338 & 0.516 & 0.599 \\
TB-TB2 & 0.783 & 0.784 & 0.01114 & 0.762 & 0.805 \\
TB-TB3 & 0.815 & 0.815 & 0.00805 & 0.800 & 0.830 \\
TB-TB4 & 0.635 & 0.637 & 0.01780 & 0.603 & 0.665 \\
TB-TB5 & 0.680 & 0.679 & 0.01934 & 0.644 & 0.712 \\
\hline & & & & \\
\hline
\end{tabular}

Later, from the analysis of the path-coefficient, we can deduce the significance of all the links, except the link between personal trait and travel behavior (see Table IV and Figure 2). 
Table 4. Bootstrap results for path coefficients

\begin{tabular}{llllll}
\hline & Original & Mean.Boot & Std.Error & perc.025 & perc. 975 \\
\hline AT-> TB & 0.17355 & 0.17798 & 0.0272 & 0.1274 & 0.228 \\
PT-> TB & 0.00343 & 0.00411 & 0.0182 & -0.0329 & 0.039 \\
CM-> TB & 0.17330 & 0.16951 & 0.0258 & 0.1264 & 0.231 \\
PBC -> TB & 0.36450 & 0.36561 & 0.0271 & 0.3203 & 0.421 \\
NPI -> TB & 0.21941 & 0.21763 & 0.0175 & 0.1846 & 0.254 \\
\hline
\end{tabular}

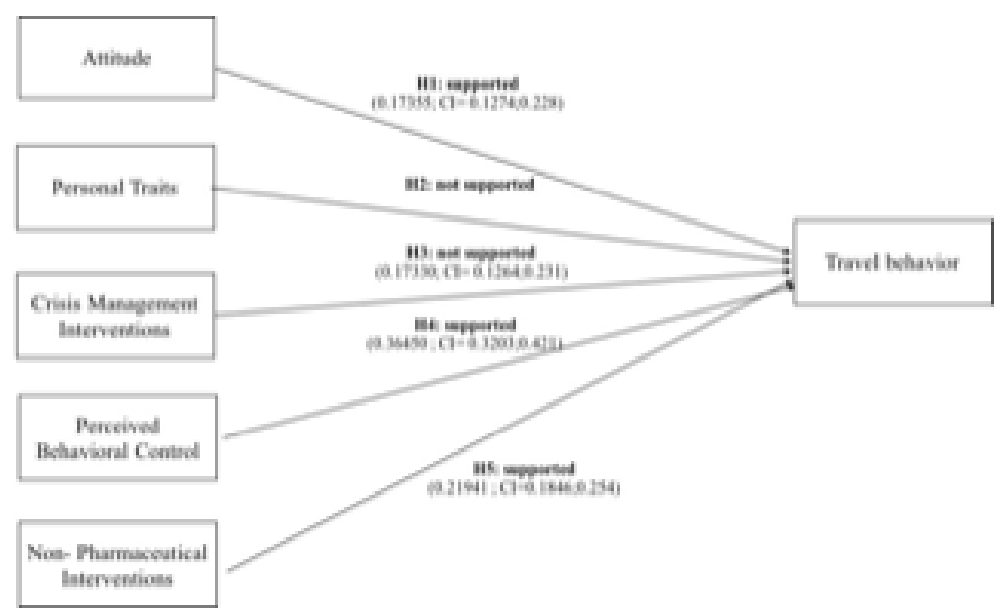

Figure 2. The Link between Personal Trait and Travel Behavior

The attitude was significant and positively associated with traveling behavior, thus providing support for H1 (path coefficient $0.1735 ; \mathrm{CI}=0.1274 ; 0.228$ ). The path coefficient of personal traits on travel behavior is not significant ( $\mathrm{CI}=-0.0329 ; 0.039)$, so $\mathrm{H} 2$ was not supported.

Crisis management interventions also impact significantly and positively on travel behavior (path coefficient= 0.17330 with $\mathrm{CI}=0.1264 ; 0.231$ ). Therefore, H3 was well supported. The coefficient of perceived behavioral control and travel behavior implies the effect is positive and significant (path coefficient $=0.36450$; $\mathrm{CI}=0.3203 ; 0.421$ ). Therefore, $\mathrm{H} 4$ is also confirmed.

Finally, non-pharmaceutical interventions showed a significant and positive relationship with travel behavior (path coefficient $0.21941 ; \mathrm{CI}=0.1846 ; 0.254$ ).

Finally, we apply a group comparison in PLS-Path Modeling (Chin, W.W, 2003) in order to verify whether significant differences between the two groups in terms of path coefficient exist (Table 5). The null and alternative hypothesis to be tested are:

¿H $\triangle \_$: path coefficients are not significantly different.

『H $\__{-}$: path coefficients are significantly different.

Table 5. Group Comparison: G1 (Female) vs G2 (Male)

\begin{tabular}{llllllll}
\hline & global & Group.Female & Group.Male & diff.abs & t.stat & p.value & sig.05 \\
\hline AT->TB & 0.1735 & 0.1811 & 0.1630 & 0.0182 & 0.2384 & 0.4058 & no \\
PT->TB & 0.0034 & 0.0096 & 0.0098 & 0.0002 & 0.2177 & 0.4138 & no \\
CM->TB & 0.1733 & 0.1624 & 0.1899 & 0.0274 & 0.4630 & 0.3217 & no \\
PBC->TB & 0.3645 & 0.3903 & 0.3251 & 0.0652 & 1.1726 & 0.1206 & no \\
NPI->TB & 0.2194 & 0.1896 & 0.2559 & 0.0662 & 1.7362 & 0.0413 & yes \\
\hline
\end{tabular}

In our case, we compare the path coefficients for groups male and female (Table V and Figure 3). Results from this analysis show that there is a different significant link between the non-pharmaceutical interventions and travel behavior. In particular, the effect of this relationship is higher in males. 


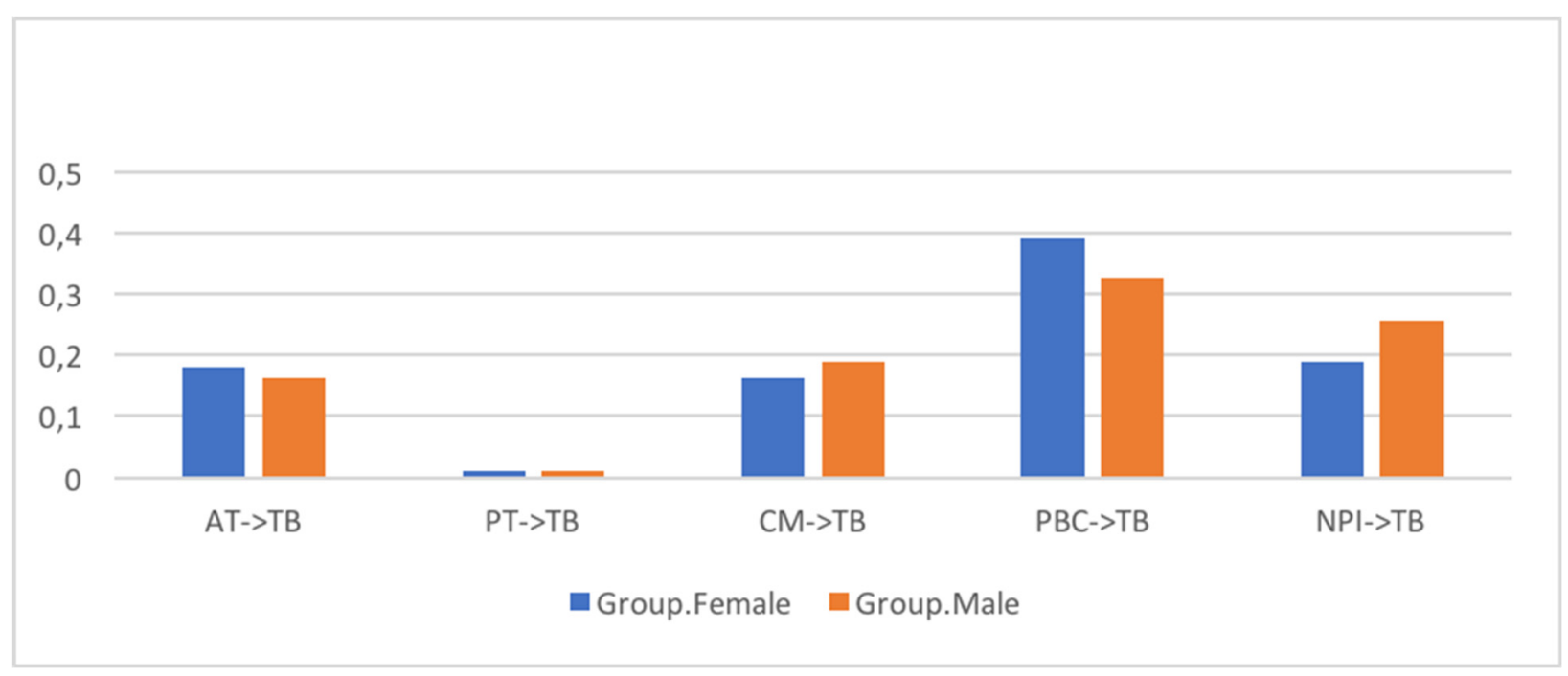

Figure 3. The path coefficients for group male and female

\section{Discussion}

This study investigated the impact of a global pandemic, Coronavirus, on travel behavior by integrating crisis management with attitude, personal traits, perceived behavioral control and non-pharmaceutical interventions. The results suggest that, with the exception of personal traits, all of these impacted travel behavior during the COVID-19 pandemic.

While crisis management intervention was the main factor in making travel plans, non-pharmaceutical interventions (NPIs) came in second. Non-pharmaceutical interventions were measured in terms of what one knows regarding how the Coronavirus affected their upcoming destination and the necessary precautions to be taken. During pandemics, crises influence the method of travel and travelers take certain non-pharmaceutical interventive actions before and during their travels.

Attitudes and behaviors evolve over time (Paulssen et al., 2013), and since the current pandemic situation is ever-evolving, then perhaps at that moment in time when the data was collected, the attitudes of the participants were not defined well enough to significantly influence their travel behavior.

As indicated by our results, apart from perceived behavioral control, the other two core variables (non-pharmaceutical interventions and crisis management interventions) are Coronavirus crisis specific.

The present study validates the conceptual model showing the most relevant variables that impact travel behavior during the Coronavirus pandemic. Personal traits were the only variable that recorded a negative relationship with travel behavior. In the context of this study, personality traits were related to how one's activities were impacted by this pandemic. This finding is supported by previous research (Sönmez \& Graefe, 1998; Van Acker et al., 2016) in which personality traits influence travelers to travel to and/or avoid certain places. The areas affected by Coronavirus are among those that travelers avoid for understandable reasons. Another implication for travel companies and destinations based on the findings of this study is that destinations should promote activities that support social distancing and take precautions against Coronavirus, which will be likely to gain traveler confidence and further induce travel.

\section{Implications and Conclusion}

The current study has significant practical and theoretical implications. It adopted the extended model of goal-directed behavior but also included the crisis management intervention. In terms of practical implications, it has become apparent that firms and governments should understand and implement integrated risk management and crisis management strategies.

Attitudes of travelers was another factor influencing travel behavior. Hoteliers should review their cleaning and sanitation practices for rooms and public areas and highlight these in their marketing campaigns. Restaurants should review their cleaning and sanitation practices and implement social distancing in seating and waiting areas and highlight these in their marketing efforts until the Coronavirus disappears. This pandemic has raised awareness in the general public concerning hygiene. Unlike when previous pandemics happened, the internet and 
news feeds in the current times are much more aggressive and accessible, which is beneficial as it keeps the population informed but can also be a means of spreading fear and panic amongst us.

Although personal traits usually strongly influence travel behavior, these relationships weaken in the case of a pandemic. Our results show this as the only variable having a negative relationship with travel behavior. This makes sense as research has shown that travelers travel to and/or avoid certain areas based on their personal feelings. The areas impacted by Coronavirus are naturally among those that travelers avoid at this time. Tourist destinations need to reassure travelers that these areas are again safe for travel. This will likely decrease the risk factor, therefore influencing travelers to travel to this region. As other regions beat the Coronavirus, travel will probably start again.

The limitation of this study is that the questionnaire was redistributed during the period when Coronavirus was still in its early stages, and the fullest extent to which the impacts could grow were not yet known. Future research could collect data during the peak of the Coronavirus and after it is finished and compare results to this study to see the impact of the severity of the crisis on travel behavior.

\section{References}

Ajzen, I. (2002). Perceived behavioral control, self - efficacy, locus of control, and the theory of planned behavior. Journal of Applied Social Psychology, 32(4), 665-683. https://doi.org/10.1111/j.1559-1816.2002.tb00236.x

Al-Tawfiq, J. A., Zumla, A., \& Memish, Z. A. (2014). Travel implications of emerging coronaviruses: SARS and MERS-CoV. Travel Medicine and Infectious Disease, 12(5), 422-42. https://doi.org/10.1016/j.tmaid.2014.06.007

Avci, U., Madanoglu, M., \& Okumus, F. (2011). Strategic orientation and performance of tourism firms: evidence from a developing country. Tourism Management, 32(1), 147-157. 10.1016/j.tourman.2010.01.017

Biggs, D., Hall, C. M., \& Stoeckl, N. (2012). The resilience of formal and informal tourism enterprises to disasters: reef tourism in Phuket. Thailand Journal of Sustainable Tourism, 20(5), 645-665. http://dx.doi.org/10.1080/09669582.2011.630080

Bundy, J., Pfarrer, M. D., Short, C. E., \& Coombs, W. T. (2017). Crises and crisis management: integration, interpretation, and research development. Journal of Management, 43(6), 1661-1692.

Campo, S., Díaz, A. M., \& Yagüe, M. J. (2014). Hotel innovation and performance in times of crisis. International Journal of Contemporary Hospitality Management, 26(8), 1292-1311. https://doi.org/10.1108/IJCHM-08-2013-0373

Chin, W.W. (2003). A permutation procedure for multi-group comparison of PLS models. In M. J. Vilares, M., Tenenhaus, M., Coelho, P., Esposito Vinzi, V., Morineau, A. (Eds.), PLS and Related Methods - Proceedings of the International Symposium PLSO3 (pp. 33-43).

Cobanoglu, C., Berezina, K., Cavusoglu, M., Ciftci, L., \& Ali, F. (2016). Using Mechanical Turk Respondents as a Replacement of General Public in Online Surveys. Proceedings International Interdisciplinary Business-Economics Advancement Conference (6th, pp. 34-45). Retrieved from https://scholarcommons.usf.edu/anaheipublishing/vol12/iss2016/1/

Coronavirus: Oil price collapses to the lowest level for 18 years. (2020, March 30). Retrieved from https://www.bbc.com/news/business-52089127

COVID-19 Dashboard by the Center for Systems Science and Engineering (CSSE) at Johns Hopkins University (JHU) (2020). Retrieved from https://gisanddata.maps.arcgis.com/apps/opsdashboard/index.html\#/bda7594740fd40299423467b48e9ecf6

Cowling, B. J., Fung, R. O., Cheng, C. K., Fang, V. J., Chan, K. H., Seto, W. H., \& Houck, P. M. (2008), Preliminary findings of a randomized trial of non-pharmaceutical interventions to prevent influenza transmission in households. PloS one, 3(5). https://doi.org/10.1371/journal.pone.0002101

David, D. (2020). Coronavirus: Oil price collapses to lowest level for 18 years. Retrieved from https://www.bbc.com/news/business-52089127

Deeper Revenue Hit from COVID-19. (2020). Retrieved from https://www.iata.org/en/pressroom/pr/2020-03-24-01/

Ekstein, N. (2020). The coronavirus's effect on tourism will carry into 2021, experts say. Bloomberg. Retrieved 
from

https://www.bloomberg.com/news/articles/2020-02-13/coronavirus-s-effect-on-tourism-will-carry-into-202 1-experts-say

Enright, M. J., \& Newton, J. (2004). Tourism destination competitiveness: a quantitative approach, Tourism management, 25(6), 777-788. https://doi.org/10.1016/j.tourman.2004.06.008

Filimonau, V., \& De Coteau, D. (2020). Tourism resilience in the context of integrated destination and disaster management (DM2). International Journal of Tourism Research, 22(2), 202-222. https://doi.org/10.1002/jtr.2329

George, R., \& Swart, K. (2012). International tourists' perceptions of crime-risk and their future travel intentions during the 2010 FIFA World Cup ${ }^{\mathrm{TM}}$ in South Africa. Journal of Sport \& Tourism, 17(3), 201-223. https://doi.org/10.1080/14775085.2012.734060

Ghebreyesus, T. A. (2020). How the World Health Organization works with all people, everywhere. Retrieved from https://www.who.int/emergencies/diseases/novel-coronavirus-2019/events-as-they-happen

Ham, M., Jeger, M., \& Frajman Ivković, A. (2015). The role of subjective norms in forming the intention to purchase green food. Economic Research-Ekonomska istraživanja, 28(1), 738-748. https://doi.org/10.1080/1331677X.2015.1083875

Henderson, M., Huang, H., Grant, S., \& Henderson, L. (2009). Language acquisition in Second Life: improving self-efficacy beliefs, Same places, different spaces. Proceedings ascilite Auckland, 464-474.

Kim, M. J., \& Preis, M. W. (2016). Why seniors use mobile devices: applying an extended model of goal-directed behavior. Journal of Travel \& Tourism Marketing, 33(3), 404-423. https://doi.org/10.1080/10548408.2015.1064058

Kim, M. J., Park, J. Y., Lee, C. K., \& Chung, J. Y. (2017). The role of perceived ethics in the decision-making process for responsible tourism using an extended model of goal-directed behavior, International Journal of Tourism and Hospitality Research, 31(4), 5-25. https://doi.org/10.21298/IJTHR.2017.4.31.4.5

Kung, F. Y., Kwok, N., \& Brown, D. J. (2018). Are attention check questions a threat to scale validity? Applied Psychology, 67(2), 264-283. https://doi.org/10.1111/apps.12108

Lee, C. K., Song, H. J., Bendle, L. J., Kim, M. J., \& Han, H. (2012). The impact of non-pharmaceutical interventions for 2009 H1N1 influenza on travel intentions: a model of goal-directed behavior. Tourism Management, 33(1), 89-99. https://doi.org/10.1016/j.tourman.2011.02.006

Mansour, H. E., Holmes, K., Butler, B., \& Ananthram, S. (2019). Developing dynamic capabilities to survive a crisis: tourism organizations' responses to continued turbulence in Libya. International Journal of Tourism Research, 21(4), 493-503. https://doi.org/10.1002/jtr.2277

Meng, B., \& Choi, K. (2016). The role of authenticity in forming slow tourists' intentions: developing an extended model of goal-directed behavior, Tourism Management, 57, 397-410. https://doi.org/10.1016/j.tourman.2016.07.003

Moon, L., \& Choi, M. (2020, February 14). Global tourism to take a US\$80 billion hit and a year to shake off the effects of coronavirus outbreak. South China Morning Post. Retrieved from https://www.scmp.com/business/companies/article/3050682/global-tourism-take-us80-billionhit-and-year-s hake-effects

North, T. (2020). Global talent mobility impacted by Coronavirus related travel restrictions. Retrieved from https://www.worldwideerc.org/news/global-talent-mobility-impacted-by-coronavirus-related-travel-restricti ons

OECD Tourism and Policies 2020 (n.d.), Retrieved from https://www.oecd-ilibrary.org/sites/6b47b985en/1/1/2/index.html?itemId=/content/publication/6b47b985en \&_csp_=a806bfa96e09b9351b58695070b6c960\&itemIGO=oecd\&itemContentType=book

Past Pandemics (n.d.), Retrieved from http://www.euro.who.int/en/health-topics/communicable-diseases/influenza/pandemic-influenza/past-pande mics

Pasteur, L. (2016). Tourism Risk, Crisis and Recovery Management Guide, Council of Australian Tour Operators. Retrieved https://www.uts.edu.au/sites/default/files/20160329-Beirman-Risk-Crisis-Recovery-Tour-Wholesalers.pdf 
Paulssen, M., Temme, D., Vij, A., \& Walker, J. L. (2014). Values, attitudes and travel behavior: a hierarchical latent variable mixed logit model of travel mode choice. Transportation, 41(4), 873-888. https://doi.org/10.1007/s11116-013-9504-3

Potential impact of the Coronavirus on travel to the US: China travel marker scenario analysis. (2020). Tourism Economics.

Retrieved

from https://s3.amazonaws.com/tourism-economics/craft/Latest-Research-Docs/Coronavirus-scenarios-TE-Oxfor d-1-31-2020.pdf

Quinn, C. (2020). The Tourism Industry Is in Trouble. These Countries Will Suffer the Most. Retrieved from https://foreignpolicy.com/2020/04/01/coronavirus-tourism-industry-worst-hit-countries-infographic/

Report of the WHO-China Joint Mission on Coronavirus Disease 2019 (COVID-19) (2020). Retrieved from https://www.who.int/docs/default-source/coronaviruse/who-china-joint-mission-on-covid-19-final-report.pd f

Salcedo, A., Yar, S, \& Cherelus, G. (2020). Coronavirus Travel Restrictions, Across the Globe. Retrieved from https://www.nytimes.com/article/coronavirus-travel-restrictions.html

Schaper, D. (2020). Coronavirus Fears Lead to Canceled Flights And Concerns Within The Travel Industry. Retrieved from https://www.npr.org/2020/03/04/812026357/coronavirus-fears-lead-to-canceled-flights-and-concerns-within -the-travel-indust

Scott, P. (2020, February 23). Impact of the Coronavirus Ripples Across Asia: 'It has been quiet, like a cemetery'. Retrieved from https://www.nytimes.com/2020/02/23/travel/coronavirus-asia-tourism.html

Sheikh, K. (2020, March 16). No More Than 10 People in One Place, Trump Said. But Why? Retrieved from https://www.nytimes.com/2020/03/16/health/coronavirus-social-distancing-crowd-size.html

Slotnick, D. (2020, February 18). The coronavirus is slamming the US travel industry, with experts predicting it will wipe out more than $\$ 10$ billion in spending from Chinese visitors. Retrieved from https://www.businessinsider.com/coronavirus-impact-america-travel-industry-airlines-economy-2020-2

Sönmez, S. F., \& Graefe, A. R. (1998). Determining future travel behavior from past travel experience and perceptions of risk and safety. Journal of Travel Research, 37(2), 171-177. https://doi.org/10.1177/004728759803700209

Statement on the second meeting of the International Health Regulations. (2005). Emergency Committee regarding the outbreak of novel coronavirus (2019-nCoV) (2020, January 30). Retrieved from https://www.who.int/news-room/detail/30-01-2020-statement-on-the-second-meeting-of-the-international-h ealth-regulations-(2005)-emergency-committee-regarding-the-outbreak-of-novel-coronavirus-(2019-ncov)

Sundling, C., Nilsson, M. E., Hellqvist, S., Pendrill, L. R., Emardson, R., \& Berglund, B. (2016). Travel behaviour change in old age: the role of critical incidents in public transport. European Journal of Ageing, 13(1), 75-83. https://doi.org/10.1007/s10433-015-0358-8

The US shipped millions of masks to China earlier this year, despite warnings from experts that a pandemic was about to hit. (n.d.). Retrieved from https://www.businessinsider.com/

Thomala, L. L. (2020). Tourism industry in China - statistics \& facts. Retrieved from https://www.statista.com/topics/1210/tourism-industry-in-china/

Thomas, L., \& Berk, C. C. (2020, March 15). These retailers are closing stores to slow coronavirus outbreak. Retrieved from https://www.cnbc.com/2020/03/15/these-retailers-are-closing-stores-to-slow-coronavirus-outbreak.html

Van Acker, V., Goodwin, P., \& Witlox, F. (2016). Key research themes on travel behavior, lifestyle, and sustainable urban mobility, International Journal of Sustainable Transportation, 10(1), 25-32. https://doi.org/10.1080/15568318.2013.821003

Vinelli, A., Weller, C. E., \& Vijay, D. (2020, March 6). The Economic Impact of Coronavirus in the U.S. and Possible Economic Policy Responses. Rrom https://www.americanprogress.org/issues/economy/news/2020/03/06/481394/economic-impact-coronavirus -united-states-possible-economic-policy-responses/

Wilder-Smith, A. (2006). The severe acute respiratory syndrome: Impact on travel and tourism. Travel Medicine and Infectious Disease, 4(2), 53-60. https://doi.org/10.1016/j.tmaid.2005.04.004 
Zech, N. M. (2016). Crisis Management within the Hotel Industry: A Stakeholder Relationship Management Approach, Doctoral thesis.

\begin{tabular}{|c|c|}
\hline Construct & Item \\
\hline Attitude & $\begin{array}{l}\text { - Coronavirus has greatly affected my work and life (AT1) } \\
\text { - Coronavirus has greatly affected my attitude towards life and my way of life (AT2) } \\
\text { - I think that traveling is positive (AT3) } \\
\text { - I think that traveling is useful (AT4) } \\
\text { - I think that traveling is valuable (AT5) }\end{array}$ \\
\hline Personal traits & $\begin{array}{l}\text { - If I succeed in achieving my goal of traveling, I will be excited (PT1) } \\
\text { - If I fail in achieving my goal of traveling, I will be angry (PT2) }\end{array}$ \\
\hline $\begin{array}{ll}\text { Crisis } & \text { Management } \\
\text { Interventions } & \end{array}$ & $\begin{array}{l}\text { - All of my leisure travels have been cancelled during the Coronavirus period (CM2) } \\
\text { - Safety is one of the most important issues while traveling (CM3) } \\
\text { - Total closure of borders (CM4) } \\
\text { - More control in all countries' borders (CM5) } \\
\text { - Mandatory quarantine in case of disease diagnosis (CM6) } \\
\text { - Limitations in all countries to receive migrants and foreigners (CM7) } \\
\text { - Obligation of all citizens to be examined by medical teams (CM8) } \\
\text { - Possibility for security forces to randomly stop people on the streets to be examined (CM9) }\end{array}$ \\
\hline Perceived behavioral control & $\begin{array}{l}\text { - I will greatly reduce my travel plans in the next } 12 \text { months (PB1) } \\
\text { - I will avoid traveling to crowded big cities after Coronavirus (PB2) } \\
\text { - I am confident that if I want, I can travel (PB3) } \\
\text { - I have enough resources (money) to travel (PB4) }\end{array}$ \\
\hline Non-Pharmaceutical & - I care more about the hygiene and safety of the tourist sites after Coronavirus (NPI1) \\
\hline Interventions & $\begin{array}{l}\text { - I care more about the hygiene and safety of the means of transportation after Coronavirus (NPI2) } \\
\text { - I care more about the health of the members in the tour group after Coronavirus (NPI3) } \\
\text { - I care more about the hygiene and safety of the daily necessities while traveling after } \\
\text { Coronavirus(NPI4) } \\
\text { - I will frequently wash my hands while traveling internationally (NPI5) }\end{array}$ \\
\hline Travel behavior & $\begin{array}{l}\text { - I intend to travel in the near future (TB1) } \\
\text { - I am planning to travel in the near future (TB2) } \\
\text { - I will make an effort to travel in the near future (TB3) } \\
\text { - I will certainly invest time and money to travel in the near future (TB4) } \\
\text { - I feel very comfortable traveling right now (TB5) }\end{array}$ \\
\hline
\end{tabular}

\section{Copyrights}

Copyright for this article is retained by the author(s), with first publication rights granted to the journal.

This is an open-access article distributed under the terms and conditions of the Creative Commons Attribution license (http://creativecommons.org/licenses/by/4.0/). 